\title{
Repetition Practice and Speech-Rate Control Training's Effect on the Percentage of Correct Consonants and Ratio of Delayed Words in Apraxia of Speech Patients with Aphasia
}

\author{
Eun Young $\mathrm{La}^{\mathrm{a}, \mathrm{b}}$, Hyun Sub Sim ${ }^{\mathrm{a}}$ \\ a Department of Communication Disorders, Ewha Womans University, Seoul, Korea \\ ${ }^{b}$ Rehabilitation Center, Bethesda Hospital, Suwon, Korea
}

Correspondence: Hyun Sub Sim, PhD Department of Communication Disorders, Ewha Womans University, 52 Ewhayeodae-gil, Seodaemun-gu, Seoul 120-750, Korea

Tel: $+82-2-3277-2120$

Fax: +82-2-3277-2122

E-mail: simhs@ewha.ac.kr

Received: April 30, 2014

Revised: May 31, 2014

Accepted: June 22, 2014

This paper was excerpted some of the data from the master's thesis of the first author (2013).

\begin{abstract}
Objectives: This study looks at the effectiveness of repetition practice and speech-rate control training for improving the articulation and ratios of delayed words of patients with apraxia of speech (AOS) and aphasia. Methods: Four adult patients with AOS and aphasia participated in the study. Prior to intervention, they were asked to read aloud a controlled set of stimulus words and phrases designed to measure percentage of correct consonants (PCC) and the ratio of delayed words. During intervention all subjects received eight sessions of repetition practice and eight sessions of speech-rate control training. Two weeks after the therapy the intervention effects were measured through three sessions of trained and non-trained tasks. A statistical analysis of the results was done using the Friedman and Wilcoxon tests. Results: The results of the study are as follows: after intervention, PCC increased by an average of $35.5 \%$, with the final assessments showing a PCC maintenance effect of $82.6 \%$ (non-trained tasks) and $84.3 \%$ (trained tasks). The average ratio of delayed words was reduced by $55 \%$; this improvement was also effectively retained after intervention. Conclusion: This study demonstrates that repetition practice and speech-rate control training can dramatically improve the speech production ability of patients with AOS and aphasia, as shown by greater articulation accuracy and a reduction of delayed words.
\end{abstract}

Keywords: Apraxia of speech, Percentage of correct consonants, Repetition practice, Speechrate control training, Intervention effect, Ratio of delayed words 말실행증(apraxia of speech)은 말초·중추 신경계의 손상으로 인 해 근육의 마비, 근육의 약화 및 불협응이 없음에도 불구하고 말산 출을 위한 계획과 프로그래밍의 이상으로 나타나는 말운동장애로 분류된다(Darley, Aronson, \& Brown, 1975). 말실행증은 병소에 따 라 다양한 증상들이 중복되어 나타날 수 있는데, 뇌의 언어중추 특 히 좌뇌가 손상되었을 경우 실어증을 동반하는 경우가 많다(McNeil, Robin, \& Schmidt, 2009). 또한 중심앞이랑(precentral gyrus) 인접부위 또는 추체로(pyramidal tract)와같은 부위가 손상되었을 경우 말명료도에 영향을 주어 말실행증과 마비말장애(dysarthria) 가 동시에 나타날 수도 있다(Shipley \& McAfee, 1998). 보통 순수한
말실행증의 빈도는 매우 드물고, 실어증을 동반하는 경우가 많다 (Duffy, 2005).

말실행증 성인은 개인차가 크고, 비일관적이며, 단어가 복잡하거 나 단어의 길이에 따라 오류유형이 다르게 나타난다(Darley et al., 1975; Duffy, 2005). 말산출 시 음소왜곡과 음소착어 등과 같은 조 음오류를 보이며(Ziegler, 2002), 보속증과 같은 행동이 동반되어 나 타나는 경우가 많다(McNeil et al., 2009). 조음 시 조음기의 불규칙 한 운동형태가 관찰되고(Kent \& Rosenbek, 1983) 교대운동속도 (AMRs)과제보다는 일련운동속도(SMR)과제를 더 어려워하며 자 동구와 같은 전형적인 구문보다는 의도적이고 수의적인 발화 산출 
을 더 어려워한다(Duffy, 2005). 또한 모음보다는 초성 자음이나 자 음군에서 오류가 더 많이 나타나고(Wertz, LaPointe, \& Rosenbek, 1984) 분절의 문제로 인하여 정상인과 비교했을 때 발화 속도가 느 린 경향을 보이며 음절 사이에 휴지(pause)가 관찰된다(Kent \& Rosenbek, 1983). 모색행동(groping)과 투쟁행동과 같은 말산출 개 시의 어려움을 보이는 행동적 특징도 나타난다(Whiteside et al., 2012).

한국어를 모국어로 사용하는 말실행증 성인들은 중증도에 따라 조음위치 오류가 증가하고, 종성보다는 초성에서 오류가 더 많이 나타난다. 평음, 경음, 격음에서 대치오류를 보이고 모음을 대치하 는 경우에는 대체적으로 고모음화하는 경향이 있다(Kim, 2007).

말실행증의 말산출 오류유형 중 대치(substitutions)는 말운동 네 트워크의 기질적인 손상으로 발생하고, 실어증 환자의 대치는 음소 착어의 유형으로 언어네트워크의 손상과 연동된 현상으로 나타나 기 때문에 실어증으로 인한 음소착어와 말실행증의 변별적 진단이 쉽지 않다(Haley, Jacks, \& Cunningham, 2013). 최근에는 말실행증 의 진단을 위해 체크리스트를 통한 청지각적 진단 방식 이외에 음 향학적, 생리학적 진단기준을 활용하는 방법들이 제안되고 있고, 말실행증과 음소착어의 변별적 진단을 위한 방법으로 오류 변산성 (error variability)의 임상적 타당성에 관한 연구도 진행되고 있다 (Haley et al., 2013).

지난 2006년 신경의사소통장애학회(Academy of Neurologic Communication Disorders and Sciences)의 말실행증 치료지침위 원회(Apraxia of Speech Treatment Guidelines Committee, AST$\mathrm{GC})$ 는 말실행증 치료방법들에 대한 문헌연구의 결과를 발표하였 다. 이 연구 자료에서는 말실행증 치료방법으로 조음-운동 치료 (articulatory-kinematic treatments), 말속도/리듬 통제 치료(rate/ rhythm control treatments), 시스템 간 촉진/재조직 치료(inter-systemic facilitation/reorganization treatments), 보완대체의사소통 접근법(alternative and augmentative communication approach$\mathrm{es)}$, 기타 치료법으로 5 개 범주로 나누어 설명하였고, 치료방법에 대 한 가이드라인도 제시하였다(Wambaugh, 2006; Wambaugh, Duffy, McNeil, Robin, \& Rogers, 2006).

ASTGC가 제시한 치료법 가이드라인 중 반복연습은 치료효과 연구가 가장 많은 조음-운동 치료방법으로 소개되고 있다. 반복연 습은 치료초기 단계에서도 활용할 수 있고, 목표 말산출을 유도하 기 위해 시도되는 가장 기본적인 치료방법(Schmidt \& Lee, 2005) 으로서 일반적으로 많이 사용되는 치료법(Wambaugh, Nessler, Cameron, \& Mauszycki, 2012)으로 알려져 있다. Wambaugh 등 (2012)은 10 명의 실어증을 동반한 말실행증 성인을 대상으로 반복
연습 그리고 반복연습과 말속도/리듬 통제 훈련을 추가하여 실시 한 연구를 통하여 말실행증 성인들이 반복하여 말산출을 연습하 게 되면 관련된 말운동 프로그램이 재설정되거나 말산출을 위해 접근하는 능력이 향상된다는 것과 조음전·후를 자기 모니터링하 여 조음기 조절을 연습하기 때문에 정확도가 증가한다고 하였다. 반복연습은 그 자체로도 직접적인 치료훈련방법으로 활용될 수 있 지만, 다른 치료법과 같이 치료의 연결고리로도 활용될 수 있다 (Wambaugh et al., 2006). ASTGC의 문헌연구에 소개된 sound production treatment (SPT) 프로그램에서는 구어모델링과 반복, 단서 제공 후 모델링과 반복, 통합적 자극법, 조음위치 교수법을 위 계적인 치료프로그램으로 진행하면서 반복연습을 여러 치료과정 에서 함께 활용할 수 있음을 보여주었다.

말속도/리듬 통제 치료는 말실행증 성인들의 말속도를 감소시켜 말산출 능력을 향상시키는 치료법(Dworkin \& Abkarian, 1996)으 로, 말속도를 통제하기 위해 손가락 두드리기, 메트로놈 또는 컴퓨 터와 같이 다양한 외부 통제 방법들을 사용할 수 있다. 말실행증 성 인의 경우 통제된 말속도 훈련을 통하여 감각운동적인 피드백을 받을 수 있는 시간을 확보할 수 있고, 목표음 산출을 준비할 수 있 는 시간을 벌 수 있기 때문에 자음 정확도가 증진되는 효과가 나타 나는 것으로 알려져 있다(Dworkin \& Abkarian, 1996). Brendel과 Ziegler (2008)가 10명의 말실행증 성인에게 운율속도치료법(metrical pacing therapy)을 시행한 결과, 치료 후 말소리 산출의 오류가 현저히 감소되었고 구체적인 조음 능력이 향상되었다. 또한 말실행 증 치료를 통해 말산출 능력이 향상되면 말실행증 성인들이 보이는 모색행동과 말산출 개시의 어려움으로 나타나는 반응지연(response latency)이 감소한다는 연구도 있다(Whiteside et al., 2012).

말실행증 성인은 말운동 계획과 프로그래밍의 오류로 인하여 정 확한 발화 산출이 제한되기 때문에 치료 시 왜곡된 조음을 중심으 로 치료를 해야 하고, 조음기의 연속적인 동작과 조음의 적절한 지 점(adequate points)에 도달하는 것(Wertz et al., 1984)이 매우 중요 하다. 따라서 본 연구는 ASTGC의 문헌 연구와 선행연구에서 치료 효과로 검증도가 높은 것으로 보고된 반복연습과 정확한 말산출 을 위한 조음기 준비시간을 확보할 수 있는 말속도 통제 훈련을 위 계적으로 실시하였을 때의 치료 효과를 자음정확도와 반응지연문 항 비율에 근거하여 살펴보았다. 또한 낱말과 구문 수준의 연속발 화과제에서 정확한 말산출의 변화에 초점을 두며, 실행증 환자의 주요특성에 근거하여 살펴보았다.

본 연구에 앞서 말실행증을 동반한 브로카실어증 성인 2명을 대 상으로 한 예비연구를 진행하였다. 낱말 수준에서의 반복연습 후 말속도 통제 훈련을 실시한 결과와 말속도 통제 훈련 후 반복연습 
을 실시한 결과, 치료 순서에 따라 자음정확도에서 차이가 관찰되 었고 예비 연구결과를 토대로 반복연습 후에 말속도 통제 훈련을 실시하는 위계적인 프로그램을 마련하였다.

\section{연구 방법}

\section{연구대상자}

본 연구의 대상은 경기도의 한 병원에 입원해서 치료를 받고 있 는 성인환자 4명으로, 생활연령은 평균 55세(범위, 47-65세), 병인 은 뇌혈관계 질환(cerebrovascular accident), 발병전 우세손은 오 른손, 발병 후 경과시간은 6 개월 이상, 한국판 간이 정신상태검사 (K-MMSE: Kang, 2006)에서 23점 이상, 실어증과 말실행증을 동반 장애로 진단받았으며 평균 교육년수는 12.3 년이다. 발병 전 글자와 숫자를 읽고 쓰는 데 어려움이 없었고, 발병후 시력과 청력 등 감각 장애를 동반하지 않았으며, 마비말장애 검사에서 중복소견이 없는 자를 대상으로 하였다. 구체적인 피험자 정보는 Table 1과 같다.

P1은 51세 여성으로, 수정된 Duffy (2005)의 말운동 프로그래밍 능력평가와 Huskins checklist (1986)를 종합하여 ASR 1.6 경도 말 실행증으로 평가되었다. 비교적 간단한 문장 이해는 가능하나 다 소 복잡한 문장의 이해에는 제한을 보였다. 전보식 구문 표현이 많 고, 독특한 음도와 착어 그리고 자가수정이 많았다. 과제수행 시 낱 말의 음절수 증가에 따라 오조음이 비일관적으로 관찰되었고, 말 개시할 때 반응지연이 나타났다. P2는 47세 남성, ASR 2.1의 경도 말 실행증으로 언어이해 측면에서는 문장 수준의 이해 능력은 상당부 분 보존되어 있으나, 착어가 많아 유창성이 매우 저하되었다. 과제 수행 시 낱말의 음절수가 증가함에 따라 오조음이 비일관적으로 나타났고, 발화 개시와 발화 중 모색행동이 관찰되었다. 이전 병원 에서는 브로카실어증과 말실행증 동반장애로 평가되었으나, 언어 치료 후 $\mathrm{AQ}$ 점수도 상향되면서 실어증의 유형이 변화되었다. $\mathrm{P} 3$ 은 65 세 남성, ASR 2.0 의 경도 말실행증으로 한낱말 형태의 간단한 일
상적인 대화는 가능하나, 문법적으로 복잡한 문장 수준에서의 표 현력은 저하되었다. 말 속도는 느리고, 독특한 형태로 운율의 붕괴 가 나타났다. 낱말의 음절수 증가에 따라 오조음이 비일관으로 관 찰되고, 모색행동도 나타났다. 연구 초기에는 자발화가 거의 관찰 되지 않았고, 발화 형태도 부정적인 반응(예: 몰라)이 다수였으나 신뢰관계가 형성된 후에는 구문단위의 발화도 관찰되었고, 매우 적 극적으로 과제를 수행하였다. P4는 57세 여성, ASR 3.1의 중등도의 말실행증으로 비교적 간단한 문장 이해 및 한 단어 표현은 가능하 나 말속도가 느리고, 말산출 시 독특한 형태의 운율 붕괴가 관찰되 며, 낱말 길이에 따른 비일관적인 오조음과 눈을 감고 소리산출 없 이 입모양으로만 소리를 찾는 모색행동이 관찰되었다. 모든 피험자 는 언어치료 외에 주 5 회의 작업치료와 운동치료를 받았다.

\section{피험자 선별을 위한 평가도구}

피험자 선별을 위한 진단검사를 위해 K-MMSE (Kang, 2006)를 실시하였다. P.K-WAB (Kim \& Na, 2001)의 결과를 토대로 $\mathrm{AQ}$ 를 구하고, Kertesz (1982)의 실어증 분류표에 준하여 실어증 유형을 분류하였다. 말실행증 평가는 Duffy (2005)의 말운동 프로그래밍 능력 평가과제(Tasks for Assessing Motor Speech Programming Capacity; apraxia of speech)를 한국어에 맞춰 문항을 수정하고, STAND (Kim \& Huh, 2011)의 말실행증 평가과제 내용을 포함하 였다. 수정된 말실행증 평가는 체크리스트 방식으로 문항의 과제 를 수행할 수 있는가(+), 수행할 수 없는가(-)를 통하여 말실행증 여 부를 확인하였다. 말실행증의 중증도는 Huskins (1986)의 말실행 증 평가자료를 활용하였다. Huskins (1986)의 중증도 평가는 각 문 항에 대하여 정상범주의 0점에서 매우 심한 중증(very severe)의 5 점으로 평정하고, 평균점수(ASR)를 계산하여 중증도를 변별하였 다. 구강기능의 근육 및 운동력을 평가하기 위해 구강조음기관의 기능선별검사(Oral Speech Mechanism Screening Examination: St. Louis et al., 1981)에서 입술, 혀, 턱, 구강 부분만 선별하여 시행

Table 1. Participants' basic information

\begin{tabular}{lcccc}
\hline & P1 & P2 & P3 & P4 \\
\hline Gender/age (yr) & F/51 & M/47 & M/65 & F/57 \\
CVA location/type & Lt. thalamus \& BG ischemic & SAH, ruptured aneurysm Lt. MCA & Lt. MCA ischemic & Lt. BG ischemic, IVH, SAH \\
Time post-onset (mo) & 20 & 8 & 10 & 35 \\
A0 & 38.9 & 58.8 & 38.9 & 42.8 \\
Type of aphasia & Broca & Conduction & Broca & Broca \\
AOS ASR/severity & $1.6 /$ mild & $2.1 /$ mild & $2.0 /$ mild & $3.1 /$ moderate \\
Dysarthria & Absent & Absent & Absent & Absent \\
\hline
\end{tabular}

$\mathrm{CVA}=$ cerebrovascular accident; $\mathrm{BG}$ = basal ganglia; $\mathrm{SAH}=$ subarachnoid hemorrhage; $\mathrm{MCA}=$ middle cerebral artery; IVH=intraventricular hemorrhage; $\mathrm{AO}=$ aphasia quotient on the Korean version-Western Aphasia Battery; AOS = apraxia of speech; ASR=average severity rating on the Huskins checklist (Huskins, 1986). 
하였고, Duffy (2005)의 마비말장애 평정 척도(dysarthria rating scale)를 번안하여 활용하였고, 단, 말실행증 평가와 중복되는 AMRs 와SMR과제는 말실행증 평가결과로만 활용하였다.

\section{치료 도구}

반복연습을 위한 훈련낱말은 REVT (Kim, Hong, Kim, Jang, \& Lee, 2009)에서 2음절 단어 20개, 3음절 단어 20개, 4 음절 단어 10 개, 총 단어 50 개를 무작위로 선정하여, 50 개 훈련낱말을 신명조체 80 포인트로 인쇄하여 한 카드에 한 낱말이 들어가도록 훈련카드를 제작하였다. 말속도 통제 훈련을 위해서는 Microsoft Office Power Point 2007의 애니메이션 기능을 이용하여 컴퓨터 모니터에 제시 되는 글자의 속도를 초(second) 단위로 조절하는 시각적인 통제방 법을 활용하였다. 말속도통제 훈련과제는 REVT (Kim et al., 2009) 에서 무작위로 선정한 낱말들로 명사+조사+동사기본형의 구문단 위의 5-9음절로 음절 수를 통제하여 30개의 구문을 제작하였다. 각 피험자의 훈련 말속도를 설정하기 위해 각 피험자의 낱말 반복 연습 첫 회기의 녹화자료를 분석하여 음절 당 산출시간(초)을 측정 하였고, 말속도 통제 훈련에서는 측정된 말속도보다 $50 \%$ 를 느린 속 도를 훈련 말속도로 사용하였다. 말속도 통제 기준 설정을 위한 녹 화 자료에는 모색행동, 착어나 자가수정으로 소요된 시간이 모두 포함되어 있다.

\section{치료 방법}

치료를 시작하기 전에 음절수를 통제한 낱말 10 개 문항과 구문 10 개 문항을 1 번씩 소리 내어 읽게 함으로써 피험자들의 자음정확 도와 반응지연문항 비율을 측정하였다. 연구자는 피험자들에게 어 떠한 시범도 제공하지 않았고, 착어나 조음 오류, 모색행동으로 반 응시간 이내에 정조음하지 못하더라도 과제를 순서대로 진행하였 다. 단, 5 초의 반응 시간 이내에 첫음절이 정조음하여 산출된 경우에 만 반응이 종결될 때까지 관찰하여 최종 반응을 결과로 평가하였다.

반복연습은 매 회기당 3 회에 걸쳐 진행되었고, 첫 회에 10 개의 낱 말을 각각 5 회씩 반복하여 소리 내어 읽게 하였다. 이후 잠시 쉬는 시간을 갖고, 동일한 과정을 2 회 반복하게 함으로서, 피험자마다 1 개의 낱말을 총 15 번 반복하여 읽게 하였다. 피험자가 낱말 자극을 정조음하지 못할 경우 연구자는 1 회의 시범을 보여주었고, 피험자 의 요구가 있을 경우에도 1 회에 한하여 시범을 보여주었다. 시범을 제공할 때는, 정확한 말소리 정보를 시각적, 청지각적으로 제공할 뿐 구체적인 조음 방법이나 조음기관들의 활용 방법들에 대해서는 설명하지 않았다. 반복연습은 8 회기 동안 진행되었다.

말속도 통제 훈련은 1 회기에 10 개의 구문이 사용되었다. 처음 3
초 동안은 컴퓨터 화면에 백지화면이 제시되고 그 후에 바로 2어절 의 훈련구문이 황록색의 글씨로 컴퓨터 화면 전체에 제시하였다. 컴퓨터 프로그램에 미리 입력된 각 피험자의 말속도에 따라 황록색 의 개별 글자 색이 검정색으로 변하게 되면 피험자는 색의 변화속 도에 맞춰 구문을 소리 내어 읽게 하였다. 훈련프로그램은 과제의 음절 길이에 따라 총 소요시간이 다르게 설정되었고, 구체적인 시 범 방법과 기준은 반복연습과 동일하다. 말속도 통제 훈련은 8 회기 동안 진행되었다.

치료 후 검사는 치료 전 검사와 동일한 과제로 진행하였다. 치료 종결 2주 후에 유지 평가를 훈련과제와 비훈련과제로 나눠 3회기 에 걸쳐 진행하였다. 훈련과제는 치료 중 활용되었던 자극을 무작 위로 선택한 뒤, 음절수만 통제하여 제작하였다. 비훈련과제의 낱 말과제는 보스톤이름대기검사(Korean version-Boston Naming Test: Kim \& Na, 1997)에서 음절수를 맞춰 구성하였고, 구문 자극 은 REVT (Kim et al., 2009)의 단어 중 치료에 활용되지 않은 단어 들로 치료 자극과 동일한 기준으로 제작하여 활용하였다. 유지 평 가 시 매 회기당 훈련과제와 비훈련과제는 각각 낱말 10 개 항목, 구 문 10 개 항목으로 구성되어 있다.

\section{연구 절차 및 자료 분석}

치료의 전 과정은 SONY의 HD bloggie MHS-PM5를 사용하여 녹화하였다. 자음정확도 평가를 위해 녹화된 피험자의 발화 중 왜 곡, 대치, 첨가, 생략, 알아들을 수 없는 반응, 보속 현상의 발화, 착 어로 인한 계속된 자가 수정 등 피험자의 발화를 모두 전사하였다. 한 낱말에서 착어나 모색행동, 자가수정이 빈번하게 반복될 경우 전사 후 마지막 반응을 자음정확도 평정자료로 사용하였다. 자음 정확도와 반응지연문항비율은 치료 전, 치료 후, 그리고 유지평가 의 훈련과제 및 비훈련과제를 측정하였다.

자음정확도는 조음해야 할 총 자음수를 바르게 조음한 자음수 로 나눈 뒤 100 을 곱하여 \%로 계산하였다. 말산출반응시간(speech reaction time)은 자극 제시 후 피험자가 구어적인 반응을 시작할 때까지 소요되는 시간(latency)으로, 본 연구에서는 예비연구에서 임의 선별한 1 회기의 평균 반응시간을 계산하였고, 결과 5 초의 반 응시간을 정하여 반응지연의 기준으로 정하였다. 과제 제시 후 소 요된 말산출 반응시간을 초 단위로 계산하여 5 초의 반응시간을 기 준으로 초과/이하(+/-)의 반응지연 문항 비율을 측정하였다. 반응 지연문항비율은 제시된 총 문항을 초과한 문항수로 나눈 뒤 100 을 곱하여 \%로 계산하였다.

자료의 통계적 분석을 위해 SPSS ver. 12 for Windows 프로그램 을 사용하였다. 치료 전-치료 후-유지 단계에서의 자음정확도와 반 
Table 2. Range and mean (SD) of PCC and ratio of delayed words

\begin{tabular}{lccllll}
\hline & \multicolumn{2}{c}{ PCC } & & \multicolumn{2}{c}{ Ratio of delayed words } \\
\cline { 2 - 3 } \cline { 5 - 6 } & Range & Mean (SD) & & Range & Mean (SD) \\
\hline Pre-therapy & $40.6-61.3$ & $50.0(9.4)$ & & $50-90$ & $70.0(18.3)$ \\
Post-therapy & $78.4-91.7$ & $85.5(6.1)$ & & $10-20$ & $15.0(5.8)$ \\
Maintenance & & & & & \\
$\quad$ Non-trained & $79.2-87.6$ & $82.6(3.7)$ & & $10-30$ & $20.0(8.2)$ \\
Trained & $80.6-90.0$ & $84.3(4.3)$ & & $10-20$ & $17.5(5.0)$ \\
\hline
\end{tabular}

$\mathrm{PCC}=$ percentage of correct consonants.

Table 3. Data analysis through Friedman test

\begin{tabular}{lcccc}
\hline & N & Chi-square & df & Asymp. Sig. \\
\hline PCC & 4 & 9.30 & 3 & $<.05$ \\
Ratio of delayed words & 4 & 9.54 & 3 & $<.05$ \\
\hline
\end{tabular}

$\mathrm{PCC}=$ percentage of correct consonants.

$p<.05$.

Table 4. Data analysis through Wilcoxon signed-ranks test

\begin{tabular}{|c|c|c|c|c|}
\hline \multirow{2}{*}{ Comparison } & \multicolumn{2}{|c|}{ PCC } & \multicolumn{2}{|c|}{ Ratio of delayed words } \\
\hline & Z & $t$ & Z & $t$ \\
\hline Pre \& Post & -1.82 & $<.01$ & -1.85 & $<.01$ \\
\hline $\begin{array}{l}\text { Pre-maintenance } \\
\text { Non-trained } \\
\text { Trained }\end{array}$ & $\begin{array}{l}-1.82 \\
-1.82\end{array}$ & $\begin{array}{l}<.01 \\
<.01\end{array}$ & $\begin{array}{l}-1.85 \\
-1.84\end{array}$ & $\begin{array}{l}<.01 \\
<.01\end{array}$ \\
\hline $\begin{array}{l}\text { Post-maintenance } \\
\text { Non-trained } \\
\text { Trained }\end{array}$ & $\begin{array}{r}-1.46 \\
-.73\end{array}$ & $\begin{array}{l}>.01 \\
>.01\end{array}$ & $\begin{array}{l}-1.41 \\
-1.00\end{array}$ & $\begin{array}{l}>.01 \\
>.01\end{array}$ \\
\hline Non-trained \& trained & -1.82 & $<.01$ & -.57 & $>.01$ \\
\hline
\end{tabular}

$\mathrm{PCC}=$ percentage of correct consonants.

$p<.05$.

응지연문항비율의 변화가 유의미한지를 살펴보기 위해서 비모수 검정방법인 프리드만검정(Friedman test)을 시행하였고, 각 단계 간 유의미한 차이를 확인하기 위해 윌콕슨부호순위검정(Wilcoxon signed-ranks test)을 사용하여 사후 검정을 실시하였다.

전체 자료의 약 $20 \%$ 에 해당하는 자료를 무작위로 선택하여 언어 병리협동과정 대학원을 졸업하고, 성인 언어치료 임상경력 3년차 인 2급 언어치료사 연구자와 언어병리협동과정 대학원을 졸업하 고, 성인 언어치료 임상경력 5 년차의 1 급 언어치료사인 제 2 평가자 가 독립적으로 전사하였고, 분석한 후 대조하여 일치한 문항수를 구하여 관찰자간 신뢰도를 산출하였다. 관찰자 간 신뢰도 평가 결 과, $\mathrm{P} 1$ 은 $93.4 \%, \mathrm{P} 2$ 는 $98.4 \%, \mathrm{P} 3$ 은 96.9\%, P4는 90.3\%로 나타났다.

\section{연구 결과}

Table 2에서 제시된 바와 같이 4명 피험자의 자음정확도는 치료

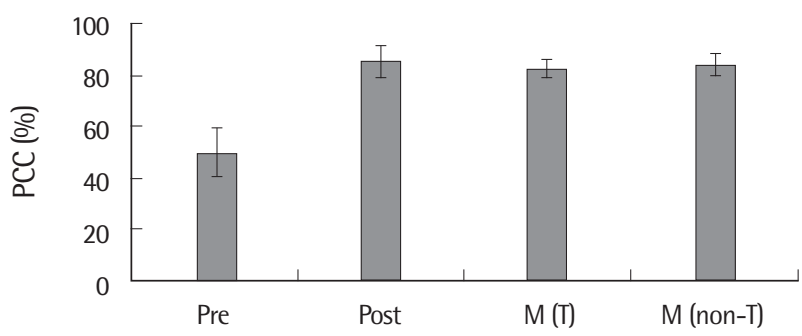

Figure 1. Mean percentage of correct consonants (PCC) among pre-therapy, post-therapy, and maintenance stages (trained and non-trained).

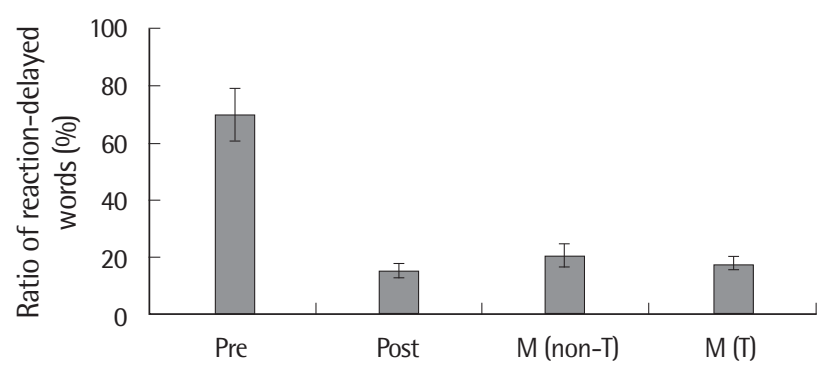

Figure 2. Mean ratio of delayed words among pre-therapy, post-therapy, and maintenance stages (trained and non-trained).

전에 비해, 치료 후 평균 $35.5 \%$ 상승하였으며, 반응지연문항비율은 평균 $55 \%$ 감소하였다. 치료 전후 및 유지단계(훈련과제와 비훈련과 제)의 단계 간 자음정확도와 반응지연 문항비율을 비교하기 위해 프리드만 검정을 실시한 결과, Table 3과 같이 유의미한 순위차를 확인하였다. 다중비교에 따른 1종 오류(type-I error)의 통제를 위 하여 유의수준을 .01 로 조정하여 윌콕슨부호순위검정을 실시한 결과는 Table 4 과 같다.

Table 4에 제시된 바와 같이 자음정확도와 반응지연문항비율 측 정치 모두 치료 전-치료 후, 치료 전-유지비훈련과제, 치료 전-유지 훈련과제 간 비교에서 유의미한 차이를 보였고, 치료효과가 훈련과 제 및 비훈련과제로 유지되고 있는 것으로 나타났다. 한편 유지단 계에서의 자음정확도는 비훈련과제보다 훈련과제에서 더 유의미 하게 높았고, 반응지연문항비율은 과제에 따라 유의미한 차이가 없 었다. 치료 전후, 유지단계에서의 훈련·비훈련 과제에 대한 자음정 확도는 Figure 1에, 반응지연문항 비율은 Figure 2에 제시하였다.

\section{논의 및 결론}

본 연구는 반복연습과 말속도 통제 훈련의 위계적인 치료 방법이 실어증을 동반한 말실행증 성인들의 정확한 조음 산출에 미치는 영향을 알아보고자 하였으며, 연구결과는 다음과 같다. 첫째, 피험 자들은 모두 치료 전보다 치료 후에 자음정확도가 유의미하게 증 
가하였다. 둘째, 치료가 종결된 후에도 증가된 자음정확도는 훈련 과제 및 비훈련과제에서도 유지되었다. 셋째, 치료 후에는 피험자 들 모두의 반응지연문항비율이 유의미하게 감소하였고, 감소된 치 료효과도 유지되었다.

이와 같은 결과는 반복연습과 말속도 통제 훈련으로 말실행증 성인들의 정확한 조음 산출 능력이 향상된 것으로 각각의 치료법 을 활용했던 선행연구와 일치하는 결과이다. 반복연습을 통하여 말실행증 성인의 정확한 말산출 능력이 향상되었다고 보고한 Wambaugh 등(2012)과 비구어적 운동학습 측면에서 반복연습으로 치 료효과를 살펴본 Schmidt와 Lee (2005)의 연구결과와 같은 맥락 에서 살펴볼 수 있다. 또한 통제된 말속도 훈련방법으로 말실행증 성인의 말소리 산출 오류가 감소하였다는 Mauszycki와 Wambaugh (2008)와 Brendel과 Ziegler (2008)의 연구결과와도 연결 지어 볼 수 있다. 선행연구들은 ASTGC의 문헌연구에서 분류한 5 개 범주 영역 에 속한 특정 치료법에 초점을 맞추었지만, 본 연구에서는 조음-운 동 치료와 말속도/리듬 통제 치료의 각각의 치료법을 2 가지 영역에 서 위계적으로 구성한 것이 선행연구와의 차이점으로 볼수 있다.

피험자별로 반복연습과 말속도 통제 훈련이 자음정확도와 반응 지연문항비율에 미친 치료효과를 각각 살펴보면 다음과 같다. P1 은 치료 전 $53.8 \%$ 에서 치료 후에 $78.4 \%$ 로, 자음정확도가 $24.6 \%$ 상 승함으로써 4 명의 피험자 중에서 가장 적은 폭의 자음정확도 증가 율을 보였다. 유지단계에서의 자음정확도는 비훈련과제에서 $79.2 \%$, 훈련과제에서 $80.6 \%$ 로 치료효과가 유지되었다. 반응지연문항비율 도 치료 전에는 $60 \%$ 이었으나 치료 후에는 $20 \%$ 로 감소하였고, 유지 평가에서는 비훈련과제에서 $20 \%$, 훈련과제에서 $20 \%$ 로 감소된 폭 을 비슷한 수준으로 유지하였다. 치료전후의 조음오류 유형의 변 화를 비교한 결과, 대치가 $62.5 \%$ 가장 큰폭으로 감소하였고, 생략, 첨가, 왜곡은 $12.5 \%$ 로 같은 비율로 감소하였다.

가장 큰 자음정확도 상승폭을 보인 P2는 치료 전에는 $44.3 \%$ 의 자음정확도를 보였으나 치료 후에는 $91.7 \%$ 을 보여 $47.4 \%$ 의 자음정 확도가 향상되었다. 유지단계에서의 자음정확도는 비훈련과제에 서 $87.6 \%$, 훈련과제에서 $90.0 \%$ 로 치료효과가 유지되고 있는 것으 로 평가되었다. 반응지연문항비율도 치료 전 $80 \%$ 에서 치료 후 $10 \%$ 로 큰 폭으로 감소하였고, 유지평가단계에는 비훈련과제에서 $20 \%$, 훈련과제에서 $10 \%$ 로 감소된 효과를 유지하였다. 치료전후의 조음 오류 유형은 대치가 $62.3 \%$ 감소, 생략은 $21.3 \%$, 첨가와 왜곡은 각각 $8.2 \%$ 감소하였다.

치료 시작 전에 가장 높은 $61.3 \%$ 의 자음정확도를 보였던 P3는 치료 후 $89.4 \%$ 로 자음정확도가 $28.1 \%$ 상승하였다. 유지단계의 자 음정확도는 비훈련과제에서 $83.2 \%$, 훈련과제에서 $85.3 \%$ 로 치료효
과가 유지되고 있는 것으로 나타났다. 반응지연문항비율의 경우 치 료 전 $50 \%$ 에서 치료 후에는 $10 \%$ 로 감소하였고, 유지평가단계에서 는 비훈련과제에서 $10 \%$, 훈련과제에서 $20 \%$ 로 비슷한 수준을 유지 하였다. 또한 치료전후로 대치가 $75 \%$, 첨가는 $13.9 \%$ 감소하였고, 생 략은 $8.3 \%$, 왜곡은 $2.8 \%$ 감소하였다.

발병 후 경과 기간이 가장 길었던 P4는 치료 전 $40.6 \%$ 로 가장 낮 은 수행력을 보였으나 치료 후에는 $82.5 \%$ 로, $41.9 \%$ 향상되었다. 유 지단계의 자음정확도는 비훈련과제에서 $80.5 \%$, 훈련과제에서 $81.4 \%$ 로 치료효과가 유지되고 있었다. 반응지연문항비율도 치료 전 $90 \%$ 에서 치료 후 $20 \%$ 로 큰폭으로 감소하였고, 유지평가단계에 서는 비훈련과제에서 $30 \%$, 훈련과제에서 $20 \%$ 으로 감소된 치료효 과를 유지하였다. 또한 치료전후의 조음오류 유형은 대치가 $68.5 \%$, 생략이 $24.1 \%$ 감소하였고, 첨가는 $7.4 \%$ 감소하였으나 왜곡의 감소 율은 변화가 없었다.

위에서 언급한 개인별 치료효과를 분석해 보면, 치료전후 자음 정확도는 78.4\%-91.7\%까지 상승하였다. 하지만 자음정확도의 상 승폭 경향성을 보면, 치료 전에 $55 \%$ 미만의 자음정확도를 보였던 피험자들(P1과 $\mathrm{P} 3)$ 은 $55 \%$ 이상의 정확도를 보인 피험자들(P2와 P4)보다 치료 후 더 큰 자음정확도의 상승폭을 보였다.

모든 피험자들이 치료 후 자음정확도가 상승하면서 조음오류의 총수가 감소하였다. 치료 전 모든 피험자들에게서 대치 오류가 가 장 높은 빈도로 나타났고, 치료 후에는 대치오류가 가장 큰폭으로 감소하였다. 기본 동사형에 종성 ‘'’을 포함하는 첨가 오류(예: 낙시 를 한다->낙시를 하다)를 중심으로 첨가 오류도 피험자 모두 감소 하였으나 오류 감소비율에 따른 유형의 순위는 피험자마다 다르게 나타났다.

$\mathrm{AQ}$ 점수가 치료효과에 영향을 미칠 수 있는지의 여부는 추후 연 구에서 고려할 필요가 있다. 예를 들면, 자음정확도의 상승 폭이 가 장 컸던 $\mathrm{P} 2$ 는 전체 피험자 중에 $\mathrm{AQ}$ 가 가장 높은 58.8 로 중등도 (moderate)였고, 그 다음 큰 상승폭을 보였던 $\mathrm{P} 4$ 의 $\mathrm{AQ}$ 가 42.8 로 최 중도-중등도(severe to moderate)였다. 상승폭이 가장 적었던 P1과 $\mathrm{P}$ 도 $\mathrm{AQ}$ 가 38.9 로 최중도-중등도의 수행력을 보였다.

발병 후 경과 시간에 따른 특별한 경향성은 관찰되지 않았다. 자 음정확도 상승폭이 가장 컸던 P2는 4 명의 피험자 중 발병 후 경과 기간이 가장 짧은 8 개월에 치료를 시작한 반면, 그 다음으로 상승폭 이 컸던 P4는 발병 후 경과 기간이 35개월로 만성기(chronic phase) 에 포함됐다. 치료 전의 자음정확도가 가장 높았던 P3의 경우 발병 후 경과 시간이 10 개월로 P1과 P4에 비해 발병 경과 기간이 짧은 편 이지만, 상승폭이 다른 피험자들에 비해 가장 적었다.

피험자들이 소리 내어 읽기를 어려워하거나, 오조음이 빈도 높게 
Erom

관찰된 자극과제문항들을 Lee, Han과 $\operatorname{Sim}$ (2004)의 한국어 조음 복잡성지표 배점기준을 참고하여 분석해 보면, 오반응이 많은 자 극과제들은 다른 과제들에 비해 조음복잡성 차원에서 차이가 있 는 것이 관찰되었다. 자극과제에 연구개음이나 이중모음이 포함되 어 있거나, 자음으로 끝나는 폐쇄형인 형태, 종성과 초성으로 연속 자음이 배치된 형태로 조음복잡성의 점수가 높을수록 오조음이 더 빈도 높게 관찰되었다.

치료단계가 낱말 반복에서 구문 말속도 통제 훈련으로 전환되는 시점에서 모든 피험자의 자음정확도가 하락하고 오조음이 증가하 는 경향이 관찰되었다. 이러한 경향성은 치료방법의 변화와 과제길 이의 증가로 이어진 난이도 상향에 따른 현상으로 판단된다. 반면, 종결 후 유지평가의 비훈련과제에서는 새로운 과제와 과제 길이에 따른 수행력의 큰 변화가 관찰되지 않았고, 상향된 수준을 유지하 였다. 이는 치료를 통하여 조음계획와 말산출 프로그래밍 단계에 서 요구되는 정확한 조음 능력이 확보되었기 때문에 새로운 말산출 과제에서도 안정적인 말산출 능력을 유지하고 있는 것으로 해석할 수 있다.

본 연구에서는 시범을 제공할 때에는 구체적인 조음기관들의 메 커니즘, 기능 및 조음 방법에 관한 설명을 하지 않았고, 단지 1 회에 한하여 시범을 제공하였음에도 불구하고, 모든 피험자들의 자음 정확도가 상승되었다. 이러한 연구결과는 말소리 산출에 관한 직접 적 교수나 지도 방법이 아닌 반복연습과 말속도 훈련만으로도 말실 행증 성인의 말산출 능력이 향상될 수 있음을 시사한다(Southwood, 1987; Wambaugh et al., 2006).

본 연구에서 사용한 두 번째 종속변수인 반응지연문항비율은 말실행증 성인들이 보이는 모색행동, 말산출 개시의 어려움, 자가 수정과 같은 행동적 특징으로 인하여 발화 개시가 지연되는 문항 의 증감을 양적으로 볼 수 있다. 모색행동은 말산출을 위한 예비행 동으로 시각적/청각적으로 조음 방법을 찾는 과정(McNeil et al., 2009)으로서, 특히 말실행증 성인의 경우 말산출을 위한 계획과 프 로그래밍의 과정에서 생긴 오류를 극복하기 위하여 조음기관을 다 양하게 활용하면서 정확한 조음방법을 찾는 과정(Wertz et al., 1984) 이다. 본 연구의 결과, 치료 후 자음정확도는 증가하는 경향을 보이 며, 반응지연문항비율은 감소하는 경향을 보였다. 이는 피험자들의 조음 산출 능력이 향상되면서 자음정확도가 상승하였고, 아울러 모색행동 및 발화 개시의 어려움으로 인해 소요된 시간이 감소한 것으로 해석할 수 있다. 이러한 연구결과는 말실행증 성인들의 정 확한 조음 산출 능력이 향상되면서 투쟁행동과 모색행동으로 인해 소요되는 시간이 감소하였다는 Whiteside 등(2012)과 Wambaugh 등(2012)의 연구와 일치한다.
결론적으로, 본 연구결과, 반복연습과 말속도 통제 훈련은 실어 증을 동반한 말실행증 성인들의 정확한 조음 산출 능력을 향상시 켜 자음정확도를 증가시키고, 발화 개시를 위한 반응지연을 감소시 킴으로써 말산출의 정확도가 증가하였다. 따라서 이러한 치료접근 법은 말실행증 성인의 말산출 능력을 향상시킬 수 있는 가능성이 있는 효과적인 방법으로, 임상 현장에서 적극적으로 활용할 수 있 는 치료전략이 될 수 있음을 시사한다.

아울러, 본 연구는 자음정확도나 반응지연시간의 분석을 통하 여 양적 분석은 간접적으로 시도하였으나 말산출 개시의 어려움과 같은 구체적인 행동적 특성에 대한 질적 분석이 제외되어 있다. 또 한 통계적 검정과정에서 치료에 따른 각각의 피험자들의 특성이 자 세히 분석되지 못한 한계가 있다. 이는 단일대상연구로 진행하거나 또는 사전사후연구 시 충분한 자료 수집을 통하여 말실행증이 갖 는 가변성을 보완할 필요가 있다.

\section{REFERENCES}

Brendel, B., \& Ziegler, W. (2008). Effectiveness of metrical pacing in the treatment of apraxia of speech. Aphasiology, 22, 77-102.

Darley, F. L., Aronson, A. E., \& Brown, J. R. (1975). Motor speech disorders. Philadelphia, PA: Saunders.

Duffy, J. R. (2005). Motor speech disorders: substrates, differential diagnosis, and management (2nd ed.). St. Louis, MO: Elsevier.

Dworkin, J. P., \& Abkarian, G. G. (1996). Treatment of phonation in a patient with apraxia and dysarthria secondary to severe closed head injury. Journal of Medical Speech Language Pathology, 4, 105-115.

Haley, K. L., Jacks, A., \& Cunningham, K. T. (2013). Error Variability and the Differentiation Between Apraxia of Speech and Aphasia With Phonemic Paraphasia. Journal of Speech, Language, and Hearing Research, 56, 891-905.

Huskins, S. (1986). Working with apraxic clients: a practical guide to therapy for apraxia. Tucson, AZ: Communication Skill Builders.

Kang, Y. W. (2006). A normative study of the Korean-Mini Mental State Examination (K-MMSE) in the elderly. Korean Journal of Psychology, 25, 1-12.

Kent, R. D., \& Rosenbek, J. C. (1983). Acoustic patterns of apraxia of speech. Journal of Speech, Language, and Hearing Research, 26, 231-249.

Kertesz, A. (1982). The Western aphasia battery. New York, NY: Grune \& Stratton.

Kim, H. H., Huh, J. H., (2011) Screening test for aphasia \& neurologic communication disorders. Seoul: Hakjisa.

Kim, H. H., \& Na, D. L. (1997). Korean version-Boston Naming Test (K-BNT). 
Seoul: Hakjisa.

Kim, H. H., Na D. L. (2001). Paradise - Korean version-Western Aphasia Battery $(P \cdot K-W A B)$. Seoul: Paradise Welfare Foundation.

Kim, S. J. (2007). A study on the characteristics of articulation errors in Korean apraxia of speech. Institute of Natural Sciences Yongin University, 12, $1-18$.

Kim, Y. T., Hong, G. H., Kim, K. H., Jang, H. S., \& Lee, J. Y. (2009). Receptive \& expressive vocabulary test (REVT). Seoul: Seoul Community Rehabilitation Center.

Lee, E. J., Han, J. S., \& Sim, H. S. (2004). The effects of the phonetic complexity disfluencies and the articulation errors of people who stutter. Korean Journal of Communication Disorders, 9, 139-156.

Mauszycki, S. C., \& Wambaugh, J. L. (2008). The effects of rate control treatment on consonant production accuracy in mild apraxia of speech. Aphasiology, 22, 906-920.

McNeil, M. R., Robin, D. A., \& Schmidt, R. A. (2009). Apraxia of speech. In M. R. McNeil (Ed.), Clinical management of sensorimotor speech disorders (2nd ed., pp. 249-268). New York, NY: Thieme.

Schmidt, R. A., \& Lee, T. D. (2005). Motor control and learning: a behavioral emphasis (4th ed.). Champaign, IL: Human Kinetics Publishers.

Shipley, K., \& McAfee, J. (1998). Assessment in speech-language pathology: a resource manual (2nd ed.). San Diego, CA: Singular Publishing Group.

Southwood, H. (1987). The use of prolonged speech in the treatment of apraxia of speech. In Clinical Aphasiology Conference, Lake of the Ozarks, MO,
277-287.

St. Louis, K. O., \& Ruscello, M. D. (1981). Oral speech mechanism screening examination (OSMSE). Baltimore, MD: University Park Press.

Wambaugh, J. L. (2006). Treatment guidelines for apraxia of speech: lessons for future research. Journal of Medical Speech Language Pathology, 14, 317321.

Wambaugh, J. L., Duffy, J. R., McNeil, M. R., Robin, D. A., \& Rogers, M. A. (2006). Treatment guidelines for acquired apraxia of speech: a synthesis and evaluation of the evidence. Journal of Medical Speech-Language Pathology, 14, 15-33.

Wambaugh, J. L., Nessler, C., Cameron, R., \& Mauszycki, S. C. (2012). Acquired apraxia of speech: the effects of repeated practice and rate/rhythm control treatments on sound production accuracy. American Journal of Speech-Language Pathology, 21, S5-S27.

Wertz, R. T., LaPointe, L. L., \& Rosenbek, J. C. (1984). Apraxia of speech in adults: the disorder and its management. Orlando, FL: Grune \& Stratton.

Whiteside, S. P., Inglis, A. L., Dyson, L., Roper, A., Harbottle, A., Ryder, J., ... Varley, R. A. (2012). Error reduction therapy in reducing struggle and grope behaviours in apraxia of speech. Neuropsychological Rehabilitation, 22, 267294.

Ziegler, W. (2002). Task-related factors in oral motor control: speech and oral diadochokinesis in dysarthria and apraxia of speech. Brain and Language, $80,556-575$. 
Eun Young La, et al. • Repeated Practices and Speech Rate Control Training for AOS

Appendix 1. 반복연습 낱말 자극의 예

\begin{tabular}{rrrrrrrrrr}
\hline & 낱말자극 & & 낱말자극 & & 낱말자극 & & 낱말자극 & 낱말자극 \\
\hline 1 & 가위 & 11 & 사과 & 21 & 거미줄 & 31 & 신호등 & 41 & 기어가다 \\
2 & 굴뚝 & 12 & 시소 & 22 & 관현악 & 32 & 세면대 & 42 & 넘어지다 \\
3 & 궁궐 & 13 & 신문 & 23 & 냉장고 & 33 & 요리사 & 43 & 독특하다 \\
4 & 난초 & 14 & 얼룩 & 24 & 단풍잎 & 34 & 장난감 & 44 & 탑승하다 \\
5 & 내장 & 15 & 잡다 & 25 & 만국기 & 35 & 주전자 & 45 & 버드나무 \\
6 & 둥지 & 16 & 장화 & 26 & 망원경 & 36 & 지하도 & 46 & 산봉우리 \\
7 & 모발 & 17 & 조명 & 27 & 무겁다 & 37 & 축산물 & 47 & 어지럽다 \\
8 & 바다 & 18 & 촛불 & 28 & 무기류 & 38 & 타박상 & 48 & 안내하다 \\
9 & 봉화 & 19 & 탄광 & 29 & 병아리 & 39 & 팔꿈치 & 49 & 용접하다 \\
10 & 뿌리 & 20 & 화분 & 30 & 소방차 & 40 & 화내다 & 50 & 평화롭다 \\
\hline
\end{tabular}

Appendix 2. 말속도통제 훈련 자극의 예

\begin{tabular}{llll}
\hline \multicolumn{1}{c}{ 구문자극 } & \multicolumn{2}{c}{ 구문자극 } \\
\hline 1 & 버섯을 주다 & 6 & 환자를 부축하다 \\
2 & 택시를 타다 & 7 & 식료품을 배달하다 \\
3 & 무릎을 누르다 & 8 & 병아리를 쓰다듬다 \\
4 & 뿔이 뾰족하다 & 9 & 불꽃놀이도 안전하다 \\
5 & 우물이 오염되다 & 10 & 할아버지가 배부르다 \\
\hline
\end{tabular}

Appendix 3. Huskins (1986)의 말실행증 체크리스트

\begin{tabular}{|c|c|c|}
\hline & 항목 & 등급점수 \\
\hline 1 & 말산출 시 조음방법을 찾는 모색행동이 시각적으로 관찰됩니까? & \\
\hline 2 & 말산출 시 모색행동이 청지각적으로 감별됩니까? & \\
\hline 3 & 발화 수준에 따라 비유창성이 관찰됩니까? & \\
\hline 4 & 말산출 시 특정 근육의 약화 없이도 전반적으로 늦은 말속도를 보입니까? & \\
\hline 5 & 빈도 높은 반복과 자가수정이 관찰됩니까? & \\
\hline 6 & 비일관적인 음소오류가 관찰됩니까? & \\
\hline 7 & 음소의 연속적인 오류가 관찰됩니까? & \\
\hline 8 & 조음복잡성에 따라 말산출의 오류가 증가합니까? & \\
\hline 9 & 비구어적인 말소리산출이 가능합니까? & \\
\hline 10 & 비구어적인 말소리의 연속시행이 가능합니까? & \\
\hline \multicolumn{3}{|c|}{ 전체 등급점수 } \\
\hline \multicolumn{3}{|c|}{ 평균 등급점수(ASR) } \\
\hline \multicolumn{3}{|c|}{ 기타: } \\
\hline \multicolumn{3}{|c|}{$\begin{array}{l}\text { *Rating scale } \\
\text { 0=feature absent; } 1 \text { =minimal; } 2=\text { =mild; } 3=\text { =moderate; } 4=\text { severe; } 5=\text { =very severe. }\end{array}$} \\
\hline & nimal; $1.5-2.5=$ mild $; 2.5-3.5=$ moderate; $3.5-4.5=$ severe; $4.5-5=$ very severe. & \\
\hline
\end{tabular}




\section{국문초록}

\section{반복연습과 말속도 통제 훈련이 실어증을 동반한 말실행증 환자의 자음정확도와 반응지연문항비율에 미치는 영향 라은영,2, 심현섭 \\ ${ }^{1}$ 이화여자대학교 대학원 언어병리학과, ${ }^{2}$ 베데스다병원 재활센터}

배경 및 목적: 실어증을 동반한 말실행증 증상을 보이는 성인들을 대상으로 반복연습과 말속도 통제 훈련을 실시하여 조음 능력의 정 확성 향상에 관한 치료 효과를 검증하고자 한다. 방법: 4 명의 실어증을 동반한 말실행증 성인을 대상으로 치료 전 검사, 낱말 반복연습, 구문 말속도 통제 훈련, 치료 후 검사, 치료 종결 2주 후에 훈련과제와 비훈련과제로 유지 평가를 실시하였다. 낱말반복연습은 매 회기 당 3 회에 걸쳐 실시되었으며, 각 피험자에게 매 회기 20 개의 훈련낱말을 각각 15 번 반복하여 소리 내어 읽게 하였다. 말속도 통제 훈련은 각 피험자의 음절 당 산출된 발화 속도를 측정하여 $50 \%$ 늦춘 속도를 기준으로 컴퓨터 프로그램을 통해 제시된 2어절 구문을, 매 회기 10 개씩 소리 내어 읽었다. 자음정확도와 반응지연문항비율을 치료 전, 치료 후, 유지단계(훈련과제및 비훈련과제)에서 측정하여 프리드 만검정과 윌콕슨부호순위검정으로 분석하였다. 결과: 자음정확도와 반응지연문항 비율은 치료 전, 치료 후, 유지단계(훈련과제 및 비 훈련과제) 사이에 유의미한 통계적 차이를 나타냈다. 자음정확도는 평균 $35.5 \%$ 상승하였고, 반응지연 문항비율은 평균 $55 \%$ 감소하였 으며, 치료 효과는 유지단계의 훈련과제와 비훈련과제에서도 유지되었다. 논의 및 결론: 말실행증 피험자 특성을 고려하여 반복연습과 말속도 통제 훈련을 실시한 결과, 피험자들의 자음정확도가 향상되었고, 발화 개시를 위한 반응시간이 감소하였다. 이러한 치료 접근법 은 말실행증을 동반한 말실행증 성인의 말산출 능력을 증진시키기 위한 조음운동 치료방법으로 활용될 수 있음을 제안할 수 있다.

핵심어: 말실행증, 실어증, 반복연습, 말속도통제훈련, 자음정확도, 반응지연문항비율

본 논문은 제1저자의 석사학위논문(2013)의 일부를 발췌한 것임.

\section{참고문헌}

강연욱(2006). K-MMSE (Korean-Mini Mental State Examination)의 노인 규준 연구. 한국심리학회지, 25, 1-12.

김수정(2007). 한국어 말실행증의 조음오류 특성 연구. 용인대학교 자연과학연구소, 12, 1-18.

김영태, 홍경훈, 김경희, 장혜성, 이주연(2009). 수용·표현어휘력검사(REVT). 서울: 서울장애인종합복지관.

김향희, 나덕렬(1997). 한국판-보스톤이름대기검사(K-BNT). 서울: 학지사.

김향희, 나덕렬(2001). 파라다이스-한국판-웨스턴 실어증 검사(P·K-WAB). 서울: 파라다이스 복지 재단.

김향희, 허지회(2011). 실어증-신경언어장애 선별검사(STAND). 서울: 학지사.

이은주, 한진순, 심현섭(2004). 조음복잡성이 비유창성과 조음오류에 미치는 영향 언어청각장애연구, 9, 139-156. 